\title{
Town Pairs, Divided Border Towns and Places of Integration: The Case of Görlitz/Zgorzelec
}

\author{
Da riusz G ierczak
}

\begin{abstract}
Twin town pairs along the German-Polish border are a relatively new phenomenon, as the new border separated some town parts from their core areas in 1945. The relations between the bordering countries have experienced several crucial changes since then. This article analyzes the demographic conditions of small cross-border urban areas in peripheral positions and their spatial development in dependency of the permeability of the border, by examining the example of Görlitz/ Zgorzelec. The focus of this article lies on the integration process of German-Polish border twin towns.
\end{abstract}

KEY WORDS urban development, demography, euroregion, Poland, Germany

\section{Introduction}

German Görlitz and Polish Zgorzelec constitute one of several twin town pairs along the German-Polish border. In Europe, the phenomenon of border twin towns emerged especially after periods of political upheaval, such as wars or the collapse of the Eastern Bloc (Waack 2000: 19). The examples along the recent German-Polish border have been in existence only since the end of World War II. German-Polish border twin towns share the same basic conditions for integration, such as political frames for urban and economic development and international relations, as well as similar economic conditions and levels of personal interchange across the border. Furthermore, all of these towns represent the same type of small cross-border urban areas in a peripheral position within the settlement network of the respective countries (Székely 2007: 242; Hardi 2010).

The geographical position referring to the border, as well as the impact of the border itself, is important for the typography of twin towns in terms of their location within the human settlement network. Their development is related to the character of the border in terms of interchange level and accessibility. Both of these factors changed many times during the short history of this border. The following classification allows an examination of the evolution of the border character by these terms (Martinez 1994).

Some borders allow no or only very limited interaction between both sides (alienated borderlands). Another type describes borders with formalized controls and strong access regulations on at least one side, which, however, allow for limited bi-national interactions (co-existent borderlands). Beside these hard categories, two types of "soft border" can be

Sociální studia / Social Studies 1/2017. Pp. 55-70. ISSN 1214-813X. 
distinguished: one with only sporadic formal controls of the crossing by persons, but usually more restrictive control of transported goods (interdependent borderlands), and another one where most restrictions are suspended and are usually not noticeable for crossers (integrated borderlands).

These four types of border, classified by Martinez, followed each other in succession on the German-Polish border, so that they can also be considered as stages of the permeability status of the border. Therefore, after a short overview of Polish-German twin towns and of the undivided town of Görlitz, the next four sections of this article track the evolution of the border, after the scheme of Martinez, and focus as well on the integration process of the German-Polish border twin towns as exemplified in Görlitz/Zgorzelec, with a particular focus on the town's urban development as an important indicator of integration (Waack 2000: 24-25). Since the most important driving force of integration is the local population, the article also discusses the demographic element.

\section{The specifics of the divided border towns along the Oder and Lusatian Neisse}

The twin towns along the recent Polish-German border are historically specific insofar as all of them are divided by the national border, while most twin towns in the history of Central Europe were divided by an inner border between the urban nucleus and a younger urban sites. Such typical twin towns were established in the territories where the Magdeburg Law came into use. In most cases, the older cities were bigger and eventually absorbed their neighbouring twin town, as in Breslau/Wrocław, with New Town (Neustadt) incorporated already in 1327 (Strauchold and Eysymontt 2016: 9-12). In Prussia, most such New Towns were incorporated in 1810, in the context of the Stein-Hardenberg Reforms which changed town regulations.

Even if the core towns of the twin pairs on the German-Polish border look back on a long past, their history as twin towns is relatively short. Each of these pairs were actually a onetown organism until 1945, when in the aftermath of the Second World War the territories east of the rivers Oder (Polish: Odra) and Lusatian Neisse (German: Lausitzer Neiße, Polish: Nysa Lużycka) were ceded to Poland. Altogether six towns were parted this way, with two of the original town cores now lying on the Polish side (namely Küstrin/Kostrzyn nad Odrą and Guben/Gubin).

Due to the destruction of the war, the former outskirts of Forst (Forst-Berge, now Polish Zasieki) and Bad Muskau (Lugnitz, now Polish Łęknica) on the Polish side, as well as of Küstrin on the German side (former town districts Kietz, Kuhbrückenvorstadt and some islands on the Oder) lost their urban character and - as a direct consequence - also the town privileges. Only Łęknica eventually obtained its own town privileges, in 1956. Nevertheless, in the face of the growing meaning of transnational spatial planning within the scope of the EU, it could in some cases be fruitful to consider also the pairs Forst/Zasieki and Kostrzyn/Küstrin-Kietz as twin towns.

The impact of all of the towns strongly declined after their division. The growth impulses in Poland have been generally much weaker in the borderlands than in Germany. The German towns are more populous than their Polish counterparts. This is especially true for Frankfurt 
and Görlitz, which have to some degree been assuming their historic functions as regional centres for the Polish towns, since Poland joined the EU in 2004.

\section{The undivided City of Görlitz}

The towns of Görlitz and Zgorzelec lie roughly halfway between Saxony's capital city Dresden and the Silesian metropolis of Wrocław. The medieval core developed at the junction of two important trade routes: the east-west Via Regia, and a branch of the north-south central German land route on the Western (now German) bank of the Lusatian Neisse.

The name of the present day town can trace its origins to "villa Gorelic", which first appeared in 1071 and reflected the Slavonic origin of the local population. As the local elites consisted of in-migrants from other parts of the Holy Roman Empire, and later on from Prussia, the town population was predominant German-speaking.

The former merchant settlement developed quickly. The area of the old town was already completely built-up by the 13 th century. Soon, the town became an important hub of political and economic power in the region. Görlitz expanded east of the Neisse already in 1492, as the city obtained woodlands on the right bank. This area was economically exploited, but remained almost unpopulated for a long time. In the course of the industrial revolution (and due to the Stein-Hardenberg Reforms) in the 19th century, the urban development of Görlitz expanded beyond its medieval walls.

The textile industry created the economic basis for the rapid urbanization of Görlitz in the $19^{\text {th }}$ century. Factories and mills were constructed on the bank of the Neisse, using the river as an energy source. Industrialization accelerated the development of the eastern suburb of Görlitz, Neißevorstadt, where a small settlement had existed since the Middle Ages. The Neisse Bridge connected the town centre with its eastern suburb (Zubrzycki 2009).

Soon, other industries, especially engineering, replaced the declining textile industry. Thanks to its location between the Saxon and the Silesian industrial areas, Görlitz quickly became one of the most important transportation hubs in this part of Germany. The functional urban centre shifted eventually from the Old Town in the direction of the railway station. Rapid population growth in the 19th century led to the extension of urban development on the eastern bank of the Neisse as well, with new bridges connecting both parts of town. A systematic development of the eastern bank did not begin, however, until the $20^{\text {th }}$ century. In 1929, as the incorporation of Moys (today Zgorzelec-Ujazd) was accomplished, the area of the town grew to $30.55 \mathrm{~km}^{2}$, with Laubaner Vorstadt (Przedmieście Lubańskie), Neißevorstadt (Przedmieście Nyskie), and Moys (Ujazd) on the opposite bank of the Neisse covering more than half of this area. The population reached 103400 in early 1945, which was the highest level in Görlitz before its division (Lammert 2010: 32). More than $90 \%$ of the inhabitants lived west of the Neisse. Building activity concentrated in the newly incorporated areas. Until 1944, there were already 5614 apartments (or $17.5 \%$ of the whole town) on the eastern bank of the river (Wenzel 2002: 10-40). Some of the new housing estates could not be completed until the Second World War, but they predetermined the development of housing after the division. 
Picture 1: View on Görlitz, 1930. The Old Town Bridge over the Lausitian Neisse links Old Town with Neißevorstadt which later became Zgorzelec

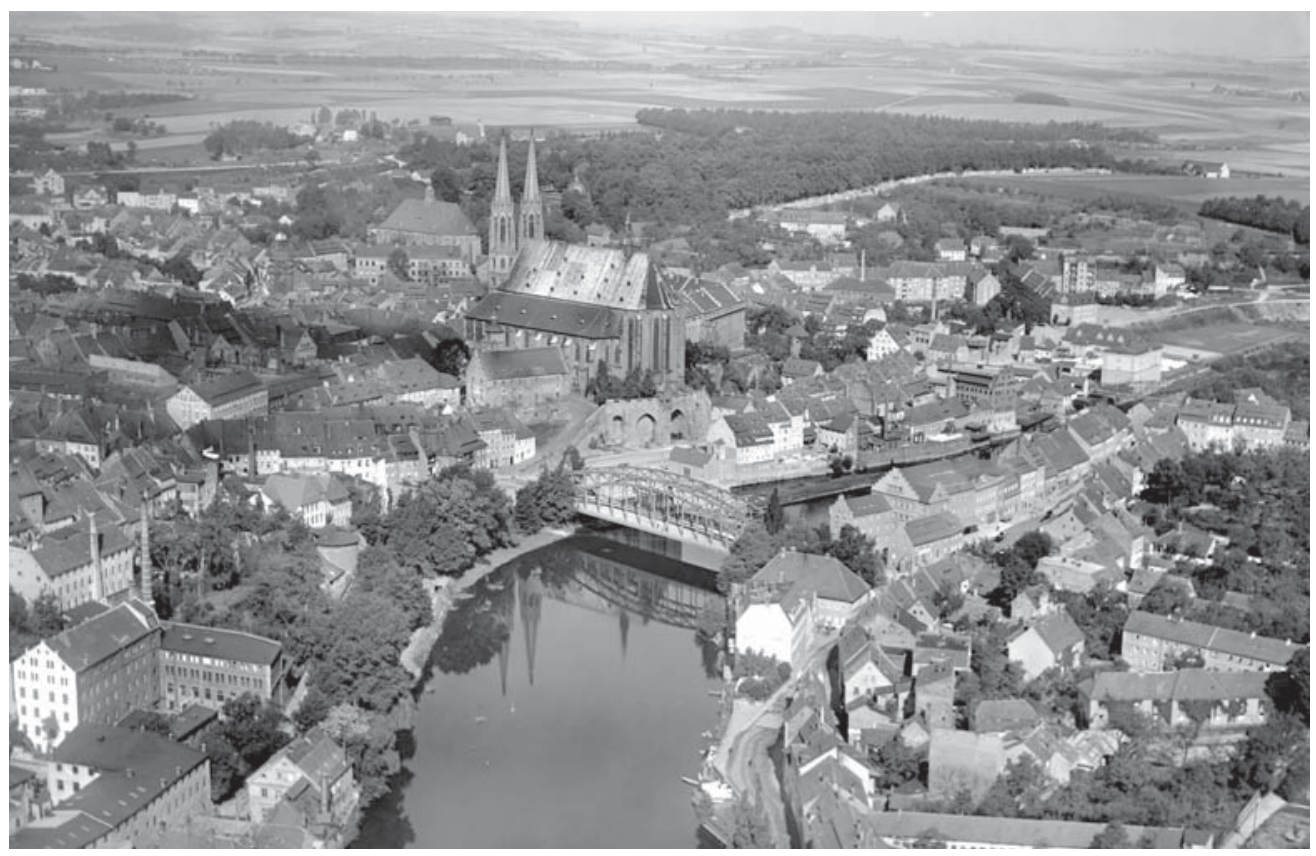

Source: Herder-Institut

\section{Broken bonds}

The old city of Görlitz was divided as a result of the Potsdam Agreement in the Polish and German part with the Lusatian Neisse forming along with the Oder the new Poland's western border. Both towns found themselves in a relatively isolated and peripheral position.

By the end of the war in 1945, 31007 people were still living in the town. Soon, the town, especially its German part, became a transit camp for German refugees and expellees from the territories lost to Poland seeking a new home in Germany. Initially, some of them, however, gathered on the border in the hope that they would be allowed to return home (Jajeśniak-Quast and Stokłosa 2000: 32). Also, displaced persons liberated from German slave labour camps were heading east. The population of Görlitz exceeded 100000 people for a few months. In the face of the overwhelming population influx, the basic supply situation became critical. The local administration felt constrained to accommodate the newcomers in the barracks of the former forced labour camp in Biesnitzer Grund (a satellite camp of the Groß-Rosen concentration camp) and to call on the migrants to leave the town as soon as possible (Opiłowska 2013: 79-82).

The dramatic population growth in Görlitz in the first years after the war revealed the urgent need for compensational areas for urban development, which could replace the lost 
town districts on the eastern bank of the Neisse. In 1949, Klingewalde and Weinhübel were incorporated, followed by Groß Biesnitz and Klein Biesnitz in 1952. The town's surface area increased up to $25.83 \mathrm{~km}^{2}$.

The former eastern districts of Görlitz constituted the new Polish town of Zgorzelice, before the Commission for the Determination of Place Names established the more recent name of Zgorzelec, in 1946 (Rospond 1948). The authorities in Zgorzelec faced the more difficult task of converting the former peripheral districts into an independent town with all the corresponding functions. Even if the area within the city limits of Zgorzelec was slightlybigger $\left(15.9 \mathrm{~km}^{2}\right)$ than the area of Görlitz on the western river bank $\left(14.6 \mathrm{~km}^{2}\right)$, the main urban area, along with the larger part of the urban infrastructure, remained on the German side (1949-1990: the German Democratic Republic; since 1990: the Federal Republic of Germany).

When the Soviets formally transferred the administration of Zgorzelec to the Polish military on May 21, 1945 (in fact, the Polish military authorities took it over ten days later), there were still about 10000 German inhabitants in the town (of about 12000 in 1944), as well as about 55000 expellees and refugees from other areas in now Polish Western territories who camped in Zgorzelec and could not leave, since the border was closed in the first days of the Polish administration (Hoche 2005: 11). In June, all Germans in the Polish-German border zone were forced to leave for Germany (Wóycicki 2013: 56-79). Every day up to 1000 Germans from other areas in the now Polish Western territories queued on the temporary floating bridge. It caused chaos on the both sides of the border, until it was repeatedly closed, in December 1945 (Bednarek 1991: 26).

Due to its location directly on the border, the town initially became a prohibited area. The resettlement of people from the former Polish eastern territories (kresy), which were incorporated into the Soviet Union in 1945, had only a minor impact here, unlike in most other places in the so-called recovered territories (i.e. pre-war German territories ceded to Poland in 1945). Among the first settlers were Polish prisoners of war and the military (Opiłowska 2013: 82-85). As professionals were needed for the setup of the communal infrastructure and other works in Zgorzelec, not all Germans were allowed to leave. 2440 Germans were still the minority population group at the end of 1945 . As soon as possible, they were replaced by Polish staff and only 17 Germans were still in the town in 1949 (Serafin, Gliński, Gostyńska and Fajerman 2011: 62-63). In 1949 and 1950, 14500 refugees from the Greek civil war caused a temporary growth in population, though a large number of them were soon relocated to other places. Another short-term population influx occurred when a migration centre for about 2000 Soviet Jews with Polish citizenship was established in Zgorzelec, in 1957. They quickly left Zgorzelec (Teichert 2011: 97).

Since the repopulation of Zgorzelec proceeded slowly, despite the high temporary fluctuation waves, urban planning in Zgorzelec was focused on the creation and reconstruction of the social and transportation infrastructure (but not in the direction of Germany), while new housing development did not play any important role in the first decade.

The division of the town had serious consequences for the urban development on both sides. Despite the damage to 1590 buildings (115 totally destroyed or heavily damaged), the historic layout of Görlitz remained almost completely intact, since Görlitz had not 
experienced larger air raids. However, the road infrastructure was seriously impacted by the withdrawing German troops who blew up every single bridge over the Neisse just two days before the end of the war (Wenzel 2002: 31-37). While industrial facilities in several factory complexes in Görlitz were dismantled and taken away to the Soviet Union as war compensation, there was almost no industry in Zgorzelec (Stokłosa 2010: 71). A lignite mine, the majority of the forest estates, and the gas works were situated in Zgorzelec, which, in turn, lacked water works, which remained in Görlitz, as well as most communal facilities like hospitals, schools and theatre. The supply situation obliged authorities on both sides of the border to cooperate. Amid the hostile relations between Germany and Poland in the first years after the war, the local authorities of Görlitz and Zgorzelec conducted a barter exchange of gas and water, starting in 1947 (Weger 2006: 48-49). The shared telephone network existed even until 1990.

Due to the peripheral position of both towns as a result of the new border along the Neisse and the demolition of bridges, the importance of the town as a transportation hub decreased markedly. The Agreement Concerning the Demarcation of the Established and the Existing Polish-German State Frontier, signed in Zgorzelec under Soviet pressure in 1950, did not bring important changes to the situation on the border between the towns. Despite the official proclaimed friendship between the Polish People's Republic and the German Democratic Republic, the relationship between the countries remained hostile for several years (Zięba and Zając 2009: 106-107). Access to the border area remained prohibited. There was no collaboration between the towns straddling the border (Jajeśniak-Quast and Stokłosa 2000: 67-72). The destroyed railway viaduct over the Neisse was not fully repaired until 1957, although the first trains had crossed already in 1956 (Wóycicki 2013: 127-128). Only one bridge for car and passenger traffic was rebuilt and opened as a border crossing, in 1958. This date marked a change in the character of the border dividing Görlitz/Zgorzelec.

\section{Sister cities}

In the course of the following decades, most urban development in Görlitz concentrated on the outskirts, especially in these new town districts. Extensive new housing estates were initially constructed in Weihnhübel, where 4300 apartments were built in 1958-1973 (Waack 2010a: 23-24). Due to the enormous needs and socialist political principles, new houses were constructed as large panel system buildings. Between 1956 and 1975, only 204 housing units (of 4 900) were built as detached houses, mainly in Landeskronensiedlung (Rat der Stadt Görlitz 1985: 13-15).

Among the important public buildings constructed in the GDR era was the "Stadium of Friendship" (built in 1951), an astronomical observatory in Biesnitz (1970), an indoor swimming pool (1972), as well as several hospitals, professional schools and colleges (Rat der Stadt Görlitz 1985: 13-17).

In the meantime, the historic urban structure of the central districts was neglected by planning authorities. The maintenance works covered the main churches and some other important public buildings. Although the local monument protection authorities voiced the need for improvement of the historical structures in the Old Town as early as 1975, there 
were almost no public investments in the old housing stock until the end of the 1980s (Bernd and Werner 2000: 16), as the GDR authorities promoted their concept of affordable modern housing, preferably in the form of estates of large apartment buildings with higher living standards. Old houses were officially considered as obsolete relics of capitalism. Moreover, GDR officials feared potential discussions concerning ownership of the pre-war buildings, as a large number of the owners lived in West Germany or West Berlin and the legal issues were not completely cleared up. Also, the policy of low rental fees left no financial leeway for larger renovations (see Vogel 2002: 38-42).

After the 1950s the population numbers decreased due to out-migration and low birth rates. Besides the intense emigration to West Germany, the numbers out-migrating to Berlin and, starting in the 1960s, to the nearby industrial town of Weißwasser (Upper Sorbian: Běła Woda) and its surroundings, were high (Bernd and Werner 2000: 14). Nonetheless, at the beginning of the 1970s, there were still 4000 people waiting for an apartment. In 1973/74, the central urban planning authorities in Berlin provided more than 6000 dwelling units for Görlitz. They were finally built in Königshufen, in the north, while the new housing areas of the 1950s and 1960s were located south of the town core. The need for housing in Görlitz was satisfied by the early 1980s (Bernd and Werner 2000: 13-25).

In 1959-65, south of Zgorzelec, the large open-pit brown coal mine of Turów (formerly Hirschfelde) was enlarged and associated power plants were built. This boosted the development of Zgorzelec, where some suppliers and a machine engineering works were established. Population growth at this time created demand for new dwellings, which were initially built to the south and northeast of the town core. Until 1980, more than 3000 new apartments were constructed in the new residential areas. The surroundings and untilled areas of the unfinished pre-war garden city estate by Paderewski Park (formerly Georg-WiesnerPark) in the north, was also built up with multi-storey concrete panel buildings known today as Osiedle Centralne ("Central Housing Estate"). In the 1980s, the Zachód ("West") housing estate in Zgorzelec was extended. The space between the town core and Ujazd was gradually built up. The concrete panel estate Słoneczne ("Sunny Estate") emerged in the south, as well as Północ ("North") in the north. Furthermore, about 500 single-family houses were constructed (Bednarek 1991: 25).

In 1966, the governments of the GDR and Poland signed an agreement about the recruitment of workers. It was one of the few steps towards concrete cooperation between the GDR and Poland which were never arranged at the local level in this period. Polish employees worked in some companies in Görlitz (Jajeśniak-Quast and Stokłosa 2000: 74-77). This agreement was associated with the shortage of the workforce in Eastern Germany due to out-migration to West Germany.

From the 1970s, at least the official relationships between the GDR and Poland distinctly improved. In 1972, most access restrictions for the citizens of Poland and GDR on the border crossings were abolished, and some official collaboration was made between the local authorities, such as the cultural exchange agreement between Görlitz and Zgorzelec in 1973. Beside some cultural events, in 1976 an urban planning competition for Polish and East German architects was held as one of the first signs of collaboration between Görlitz and Zgorzelec. In 1978, the first town map displaying the both twin towns was published. 
However, in 1980 the GDR unexpectedly implemented strict border restrictions for both GDR and Polish citizens, just after both towns had signed a partnership agreement. It was a sudden response to the rise of the opposition Solidarność movement in Poland, the state fearing that the political tensions could also affect East Germany (Jajeśniak-Quast and Stokłosa 2000: 77-95). Binational cooperation activities were interrupted. Also, the results of the planning competition to remodel the historic urban centre of Görlitz in a modern, socialist style were scrapped, officially due to the project's high costs (Waack 2010b: 30). Nonetheless, from late 1982 some local binational exchanges were resumed, but they were not as intense as previously, until the end of the GDR (Jajeśniak-Quast and Stokłosa 2000: 95-101).

Picture 2: Zgorzelec: Osiedle Centralne

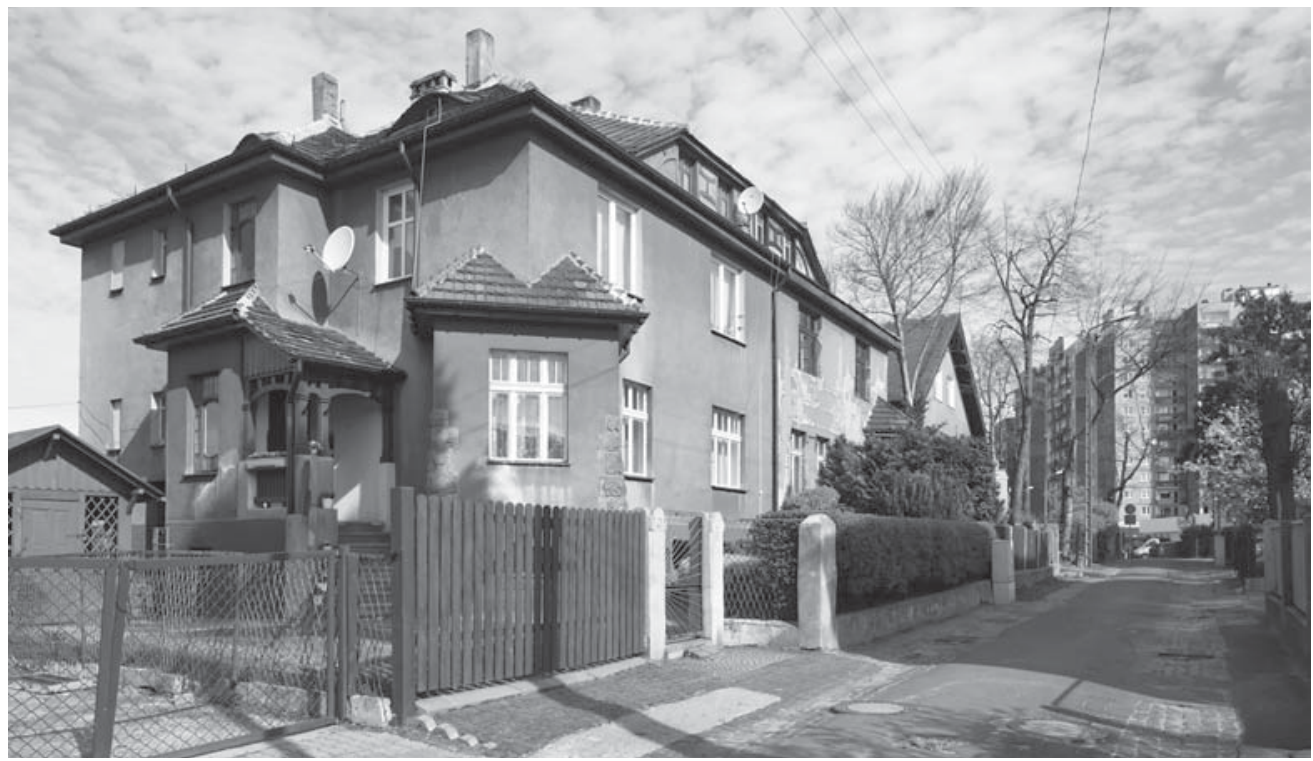

Source: Herder-Institut

\section{Timid encounter and intense cooperation}

In the 1990s, the officials of Görlitz and Zgorzelec began to take several cooperative measures. Already in 1991 the mayors of both towns signed a cooperation agreement, and several agreements between communal institutions of both towns followed (Jajeśniak-Quast and Stokłosa 2000: 101-160). In the same year, the medieval Six City Alliance (1346-1808) between Bautzen, Görlitz, Kamenz, Lauban (Lubań), Löbau and Zittau was formally revived. The original Six City Alliance had been the main source of political power and successful economic development for its members, while the modern revival (which actually, with Zgorzelec, comprises seven towns) has primarily a symbolic function and as a shared tourism promotion board. A more powerful regional cooperation initiative was the establishment 
of the Czech-German-Polish Euroregion Nisa/Neiße/Nysa, supported by the Association of European Border Regions (ABER) in the same year (Osekowski 1998). The local authorities not only supported cultural and sport exchange, but eventually established formal collaboration in many areas including tourism, education, medical care, and transportation. For example, the local bus lines connecting Görlitz and Zgorzelec, as well as the local taxis, could cross the border without queuing at the checkpoint.

In 1991, the reciprocal agreement of visa-free travel between Germany and Poland was approved, but some border restrictions, especially for Polish citizens, were still in effect. Also, private contacts led to the organization of common cultural events and grass-roots cooperation. Local businesses profited from the new opportunities, and trade exchange increased quickly. Initially, German customers especially sought out inexpensive goods and basic services in the small shops and the large open-air marketplace in Zgorzelec, while Polish customers sought more consumer choices in the West (Waack 2000: 142-153). Eventually, large shopping centres developed on the outskirts of Zgorzelec, where international, and German, companies located their shops, together with road-side sales. Due to the gap in production and rental costs between Poland and Germany, they could compete against the shopping facilities in Görlitz, and due to their assortment and the location, the large marketplace was finally closed down in 2007. The competition between Görlitz and Zgorzelec grew and the shopping centres in Germany were able to attract Polish customers due to their specialization.

The cooperation intensified after Polish accession to the EU in 2004. A symbolic expression of common bonds was the opening ceremony of the reconstructed Old Town Bridge between Görlitz and the former Neißevorstadt in Zgorzelec, right on the day of Polish accession.

Picture 3: Neissebreucke: The Old Town Bridge during the opening ceremony, May 1, 2004

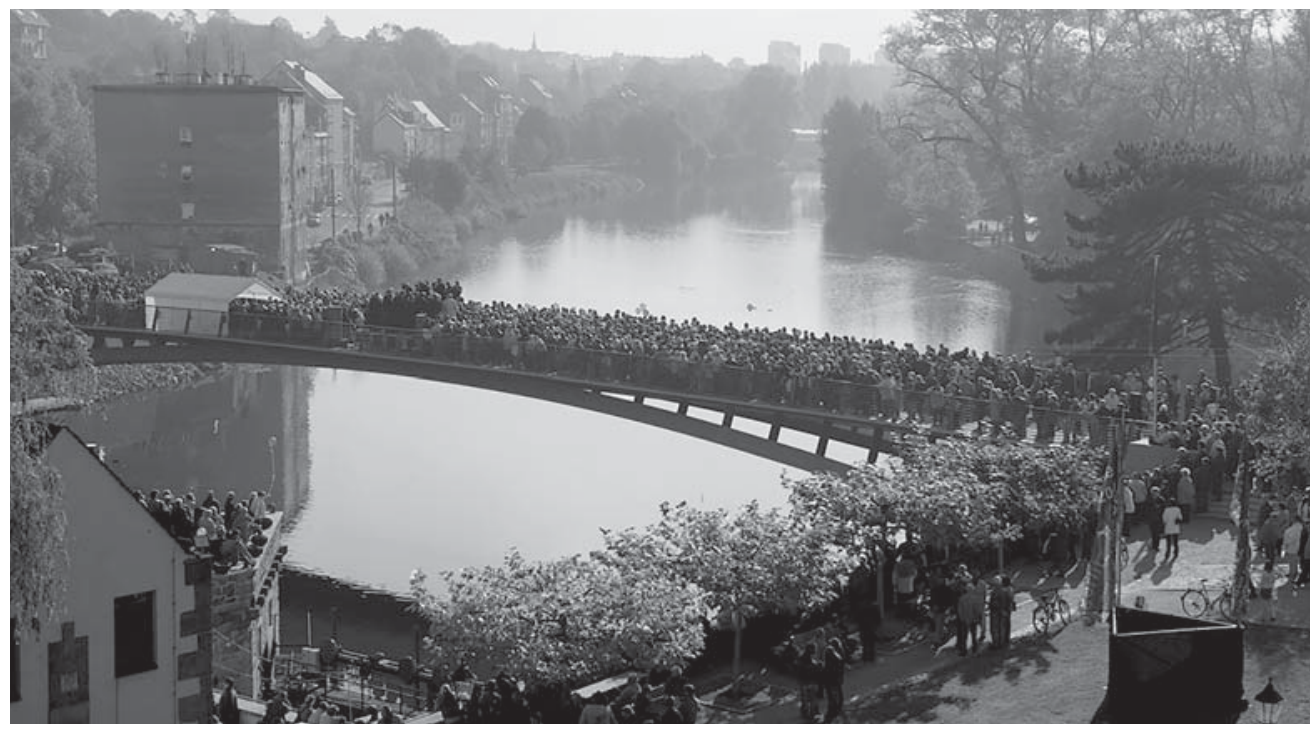

Source: Christoph Waack 
The historic part of Neißevorstadt, which lies opposite Old Town, gained a renewed vitality and urban upgrade. In the course of the redevelopment of this area, a new administrative and commercial centre emerged in the untilled areas of the former Töpferberg (today known as Plac Pocztowy).

The historical areas of Görlitz have experienced a large-scale redevelopment since the 1990s. The urban modernization has been heavily subsidised by the Federal Government as well as the federal state of Saxony, which helped to preserve the architectural heritage. The inner city with the Old Town has become an attractive and coveted residential area. Nevertheless, the town's population numbers almost halved during the 1990s (Bednarek 1991: 22) and have only slowly recovered in recent years. Its new image as one of the most beautiful towns in Germany has been reinforced by an intense media presence, since the Old Town became a popular filming location. The large panel housing estates of the socialist era, especially in the northern and western outskirts, are steadily shrinking (Stadt Görlitz 2005-2016). In the district of Königshufen alone, vacancies make up to $25 \%$ of 5800 apartments in the large socialist residential estate which was built in 1977-1986. In the face of enormous population losses, the first refurbishing measures were stopped, in 1997. In 2006, the town authorities addressed a postcard campaign to the dwellers of the large suburban panel houses and promoted the advantages of living in the refurbished Old Town. This campaign was strongly opposed by both the private housing administrative organizations of the suburban housing estates and the dwellers themselves (Sulzer 2013: 122-123). The original plans to demolish the whole estate were cancelled; however, between 2002-2008, buildings with a total of about 1000 apartments were demolished within the framework of the state's "Town-Renovation East" programme (Etscheid 2008). The ongoing demand for high quality living space in Zgorzelec is now being addressed, partly through cross-border cooperation (Waack 2010b: 37).

The privatization of the housing stocks in the early 1990s could not quickly satisfy the need for improvements in the conditions of the houses, as the new owners often did not have the resources for the necessary maintenance work, especially in Zgorzelec where purchasing power has been lower. In both towns, public and private housing and infrastructure upgrading proceeded with the help of state and EU resources.

Some of the factories built or enlarged in the GDR had to close down during the transition to a market economy. Traditional branches like optical engineering were hit hard. The openpit mine and the large power plant in the south of Görlitz were closed in 1997 and left 6000 jobless (Heppert 2000: 12). While the unemployment rate has dropped from $21.5 \%$ to $15.6 \%$ since 1998, the last large employer, Bombardier (former Waggon- und Maschinenbau Görlitz - WUMAG), reported plans for extensive job cuts in Germany. The largest employer for the population in Zgorzelec is still the mine and power plant in nearby Turów, but the machine engineering works in Zgorzelec declared bankruptcy amid the slight unemployment rate of $4.4 \%$ in 2015 (Główny Urząd Statystyczny 2017).

After 1990, retail centres, warehouses and other large-scale industries spread out into the open countryside, especially the area to the north of Görlitz and east of Zgorzelec. The extensive area of the former open-pit mine in Görlitz has been returned to nature and a leisure area has been created which could indicate the future development of similar areas on the opposite side of the border nearby to Zgorzelec. 
As a result of the administrative incorporation of several villages in the 1990s, Görlitz increased its area to $67 \mathrm{~km}^{2}$, while there were no significant changes to the town limits of Zgorzelec (which occupies $15.8 \mathrm{~km}^{2}$ ). Despite the incorporations, the population decline of Görlitz escalated after 1989. This trend changed in the last few years due to immigration from abroad, especially from Poland. Polish citizens (2 639 in May 2016) make up 60 \% of all foreign citizens (Wilkommensbündnis Görlitz 2017). As the rental charges in Zgorzelec and other Polish towns went up quickly last years, and in some segments of the real estate market prices are now even higher than in Görlitz, a new category of Polish migrants moved to the German side. Some Polish citizens live in Görlitz and work on the Polish side of the border. Both construction companies and real estate agents focus their offers on inhabitants of Zgorzelec.

As in most German towns, refugees have also contributed to the growing population in Görlitz amid the European migrant crisis. Since 2014, the number of foreign citizens in the city has almost doubled and their share grew up to $9.2 \%$ of 56188 inhabitants in 2016 (Die Stadt Görlitz 2017).

On the scale of the twin towns, for a long time the growth in Zgorzelec almost compensated for the population loss in Görlitz, so that the overall population of the combined urban area was comparable to before the division, until the radical changes that took place within the framework of the systemic transition in 1989. Then, Zgorzelec's population also started to decrease. Since their peak in 1994 (36 766), the population numbers have fallen by $15 \%$, to 31089 in $2016^{1}$. There are no significant numbers of foreigners in Zgorzelec. This led to an overall population decline in Görlitz/Zgorzelec, dropping from 113433 inhabitants in 1988 to 85725 in 2014. The recent population growth in Görlitz has changed this trend (2016: 87 277).

From the time that the A4 motorway connected Germany and Poland, in 1996, just north of the twin town limits, the border crossing point on the bridge in the inner city area became less important. This old border crossing, which had been the busiest in South Poland, caused enormous problems both for the residents and for travellers due to huge all-day traffic jams. In 1990, already 8.4 million persons passed through annually, before the visa restrictions were abolished (Bednarek 1991: 26).

The car traffic problem was not the only difficult border issue in this area in the 1990s. Due to the huge wealth and price gap between Poland and Germany (as well as the European Union, or European Community as it was at the time), the vicinity of the twin town was a hot spot of smuggling both wares and people, with many illegal migrants trying to cross the Neisse. The population of Görlitz was also afraid of increasing crime in the town caused by people from abroad. A number of crimes, especially larceny (shoplifting and theft of bikes, cars, tractors, and construction vehicles), committed by alien citizens has indeed been reported. In 2016, more almost a quarter of suspects were Polish or Czech citizens. Even if these numbers were higher in the towns and localities directly on the border, according

Numbers taken from the Central Statistical Office of Poland (Główny Urząd Statystyczny 2017). Following the more reliable data of the municipality authorities, the recent population numbers are lower: 30067 at the end of 2016 (Delegatura Krajowego Biura Wyborczego w Jeleniej Górze 2017). 
to police statistics, Görlitz and Zgorzelec are still relatively safe places, and against expectations, the crime rate has continuously decreased since EU accession (Sterbling and Burgheim 2006; Guggenheimer 2005: 90-96; Polizei Sachsen 2016).

Implementation of the Schengen Agreement in Poland in 2007 created more possibilities and legal instruments for the further increase in joint undertakings and for dealing with urban planning. Meanwhile, there are local bus lines serving both towns, but the ambitious plan to expand the tram network on the Polish side will probably have to wait a long time to be implemented. ${ }^{2}$ Despite various efforts from both the German and Polish sides since the nineties to build up cross-border cooperation, the town has not entirely recovered from the division, yet. The differences in mindset as well as different policies in the respective countries make it harder to cooperate. So, the police in Görlitz are subject to the federal state (Saxony in this case) or the municipal authorities, while policing is the responsibility of the Polish Republic in Zgorzelec. Most operations concerning cross-border issues, such as bridge renovations, must be approved by the national authorities. One of the most problematic issues in recent years has been flood management (Weiler 2013: 219-225). Still, common urban management measures, common sessions of both town councils, cross-border municipal transportation between Görlitz and Zgorzelec, and joint police patrols on both sides of the border, as well as the joint bid for the European Capital of Culture programme, have made Görlitz/Zgorzelec into a model twin town for regions characterized by distinct language frontiers, welfare gap, and historical resentments.

\section{Conclusions}

Whether the division of Görlitz in 1945 due to the new border can be considered the beginning of the existence of twin towns depends on the definition of twin towns. With regard to common developments, the tradition of twin towns like Görlitz/Zgorzelec, which was jointly proclaimed by Europe Town in 1998 (Makaro 2011: 32-34), the history is much shorter. Görlitz and Zgorzelec have gone through four phases of neighbouring relations since the division. These phases correspond to the border types defined by Martinez and are typical for twin towns on the Polish-German border, since they all share the same political development. The distinction between each phase is not always unambiguous.

Directly after the division of Görlitz, before the political situation and its impact on Görlitz/Zgorzelec had even been clarified, both towns were engaged in the restoration of basic municipal functions, seeking for solutions on both sides of the river, but the dialogue between them broke off quickly. The re-launch of the train connection from Görlitz to Zgorzelec, in 1956, and the re-opening of the border crossing point in the town, in 1958, marked the end of the first phase (alienation). In the second phase (co-existence), some limited interactions between city administrators as well as the local populations of both towns did not result in any considerable collaboration.

2 Tram lines to Moys/Ujazd existed already between 1900 and 1945. Extension plans to Schönberg (today Sulików) were abandoned due to World War I (Bufe 1976: 107-125). 
The third phase (interdependency) began as a visa-free regime was introduced for the citizens of both countries in 1972. Some official collaborative efforts between Görlitz and Zgorzelec were carried out. This phase was, however, interrupted in October 1980, as the GDR suddenly closed its borders with Poland due to the turmoil in Poland. Later in the 1980s, the border was re-opened, but the levels of access and the formal cooperation were much more restricted than in the 1970s. After the reciprocal agreement for visa-free travel between Germany and Poland in 1991, private contacts led to the cooperative organization of cultural events and grass-roots partnerships. The local authorities supported cultural cooperation and, eventually, established formal collaborations in many other areas including education, transportation, and urban planning. But some border restrictions, especially for Polish citizens, were still in effect.

The last phase (integration) began when Poland joined the EU in 2004. Formal and private relations expanded with the gradual inclusion of Poland in EU structures, especially as the Schengen Agreement came into force in Poland in 2007, and restrictions on the employment market for Polish citizens in Germany ceased in 2011.

Before 1990, the power determining the integration of the twin towns on the GermanPolish border was the state. Since the 1990s, the regional and local political bodies as well as the citizens themselves gradually became much more influential on the process of integration. Although the collaboration on the local level has been backed by regional, national and European politicians, its intensity depends mostly on the local networks and activities of the town administrators and other local actors.

Full integration into one common urban organism, as was the case for both towns built before 1945, does not seem possible in the foreseeable future. Not only the different mindsets, but also the different competencies of local, regional, and national authorities in each country make it harder to cooperate. The impact of the recent nationalist rhetoric and atmosphere propagated by the Polish central government is, however, rather small on the local level. The cooperation in urban management in Görlitz and Zgorzelec as well as many joint cultural and citizens' initiatives, have made Görlitz/Zgorzelec into a model twin town for regions characterized by distinct language frontiers, a welfare gap, and historical resentments.

\section{References}

BEDNAREK, Andreas. 1991. Görlitz gestern - Zgorzelec heute: Bilder einer Stadt. Begleitheft zur Ausstellung. Görlitz wczoraj-Zgorzelec dzisiaj: Widoki miasta. Przewodnik po wystawie. Görlitz: Städtische Kunstsammlungen Görlitz.

BERND, Uwe and Andrea WERNER. 2000. "Stadtbaupolitik und Denkmalschutz 1970 bis 1990." Pp. 13-25 in Alte Stadt mit neuer Hoffnung: 10 Jahre Stadtsanierung in Görlitz, edited by STADTVERWALTUNG GÖRLITZ. Dresden: Sandstein.

BUFE, Siegfried. 1976. Straßenbahnen in Schlesien, Stuttgart: Bufe - Fachbuchverlag.

DELEGATURA KRAJOWEGO BIURA WYBORCZEGO W JELENIEJ GÓRZE [Delegation of the National Electoral Commission in Jelenia Góra]. 2017. "Informacja o stanie rejestru wyborców 
- 2016 r.". [Information on voter registration - 2016]. Retrieved February 26, 2017 (http://jeleniagora.kbw.gov.pl/337_Wydarzenia/1/16681_Informacja_o_stanie_rejestru_wyborcow_-_stan_na_ dzien_31032016_i_30062016).

DIE STADT GÖRLITZ. 2017. "Statistische Zahlen.” Retrieved February 26, 2017 (http://goerlitz.de/ Statistische_Zahlen.html).

ETSCHEID, Georg. 2008. “Abbau Ost: Hau weg, die Häuser!” Die Zeit, January 1, Nr. 02, pp. 1-2 (http:// www.zeit.de/2008/02/LS-Goerlitz).

GŁÓWNY URZĄD STATYSTYCZNY [Central Statistical Office]. 2017. "Baza Danych Lokalnych." [Local Data Bank]. Retrieved July 19, 2017 (https://bdl.stat.gov.pl/BDL).

GUGGENHEIMER, Michael. 2005. Görlitz Schicht um Schicht: Spuren einer Zukunft. Bautzen: Lusatia.

HARDI, Tamás. 2010. "Cities, Regions and Transborder Mobility Along and Across the Border." Discussion Papers 82: 5-27.

HEPPERT, Frank. 2000. "EUROPAN IV - Wettbewerb und die Altstadtbrücke." Pp. 37-40 in Alte Stadt mit neuer Hoffnung: 10 Jahre Stadtsanierung in Görlitz, edited by STADTVERWALTUNG GÖRLITZ. Dresden: Sandstein.

HOCHE, Siegfried. 2005. "60 Jahre Kriegsende in Görlitz.” Görlitzer Magazin 18: 3-13.

JAJEŚNIAK-QUAST, Dagmara and Katarzyna STOKŁOSA. 2000. Geteilte Städte an Oder und Neiße: Frankfurt (Oder) - Stubice, Guben - Gubin und Görlitz - Zgorzelec 1945-1995. Berlin: Berlin Verlag Arno Spitz.

LAMMERT, Markus. 2010. "Die Stadt der Vertriebenen: Görlitz in der frühen Nachkriegszeit." Pp. 31-46 in Heimat und Fremde: Migration und Stadtentwicklung in Görlitz und Zgorzelec seit 1933: Beiträge der Tagung "Lebenswege ins Ungewisse”, 26.-27. Februar 2009 im Schlesischen Museum zu Görlitz, edited by Martina PIETSCH. Görlitz: Schlesischen Museum zu Görlitz.

MAKARO, Julita. 2011. "Współpraca instytucjonalna Zgorzelca i Görlitz.” [Institutional co-operation between Zgorzelec and Görlitz]. Pp. 25-46 in Zgorzelec jako miasto pograniczne w opiniach jego mieszkańców [Zgorzelec as border town in the in the opinions of its inhabitants], edited by Kamilla DOLIŃSKA and Natalia NIEDŹWIECKA-IWAŃCZAK. Wrocław: Gajt.

MARTINEZ, Oscar J. 1994. "The Dynamics of Border Interaction: New Approaches to Border Analysis.” Pp. 1-15 in Global Boundaries, edited by Clive H. SCHOFIELD. London: Routledge.

OPIŁOWSKA, Elżbieta. 2013. "Görlitz und Zgorzelec. Migration und Gesellschaftlicher Wandel im 20. Jahrhundert.” Pp. 76-90 in Colloquium Opole 2012: Miasta w przestrzeni środkowoeuropejskiej: Opole - Görlitz/Zgorzelec - Opawa po roku 1989 [Colloquium Opole 2012: Towns in Central European space], edited by Markus BAUER, Monika CHOROŚ, Bernard LINEK and Michał LIS. Opole: Państwowy Instytut Naukowy - Instytut Śląski w Opolu.

OSĘKOWSKI, Czesław and Hieronim SZCZEGÓŁA. 1998. Euroregiony na pograniczu polskoniemieckim (1991-1997) [Euroregions on the Polish-German border (1991-1997)]. Zielona Góra: Lubuskie Towarzystwo Naukowe.

POLIZEI SACHSEN. 2016. "Auswertung der Kriminalitätslage des Jahres 2015 in den Landkreisen Bautzen und Görlitz.” Retrieved February 26, 2017 (https://www.polizei.sachsen.de/de/ MI_2016_42040.htm).

RAT DER STĀDT GÖRLITZ, ed. 1985. Görlitz: Ein Führer durch die Stadt an der Oder-NeißeFriedensgrenze. Görlitz: Rat der Stadt Görlitz.

ROSPOND, Stanisław. 1948. Skorowidz ustalonych nazw miejscowości na Ziemiach Odzyskanych: wedtug uchwat Komisji Ustalania Nazw Miejscowości przy Ministerstwie Administracji Publicznej [Index of the determined locality names in the Regained Territories: according to the resolutions of the Commission for the Determination of Place Names at the Ministry of Public Administration]. Kraków: Glob. 
SERAFIN, Irena, Jan GLIŃSKI, Maria GOSTYŃSKA and Elżbieta FAJERMAN. 2011. "Entstehung von Zgorzelec / Powstanie Zgorzelca." Pp. 59-79 in Lebenswege ins Ungewisse / Drogi w nieznane: Görlitz/Zgorzelec 1933-2011, edited by Martina PIETSCH. Görlitz: Schlesisches Museum zu Görlitz.

STADT GÖRLITZ, ed. 2005-2016. Große Kreisstadt Görlitz: Statistisches Jahrbuch 2005-2015. Görlitz: Stadtverwaltung Görlitz.

STERBLING, Anton and Joachim BURGHEIM. 2006. Sicherheit und Lebensqualität in Görlitz: Ergebnisse empirischer Untersuchungen. Rothenburg/OL: Fachhochschule für Polizei Sachsen.

STOKŁOSA, Katarzyna. 2010. "Görlitz Ost wird Zgorzelec: Ankunft und Integration der polnischen Ansiedler." Pp. 69-77 in Heimat und Fremde: Migration und Stadtentwicklung in Görlitz und Zgorzelec seit 1933: Beiträge der Tagung "Lebenswege ins Ungewisse”, 26.-27. Februar 2009 im Schlesischen Museum zu Görlitz, edited by Martina PIETSCH. Görlitz: Schlesischen Museum zu Görlitz.

STRAUCHOLD, Grzegorz and Rafał EYSYMONTT. 2016. Wrocław/Breslau. Historical-Topographical Atlas of Silesian Towns. Vol. 5, edited by Peter HASLINGER, Wolfgang KREFT, Grzegorz STRAUCHOLD and Rafał ŻERELIK. Marburg: Herder-Institut.

SULZER, Jürg. 2013. “Das baulich-kulturelle Erbe der Stadt Görlitz: Chancen und Risiken.” Pp. 114-125 in Colloquium Opole 2012: Miasta w przestrzeni środkowoeuropejskiej: Opole - Görlitz/Zgorzelec - Opawa po roku 1989, edited by Markus BAUER, Monika CHOROŚ, Bernard LINEK and Michał LIS. Opole: Państwowy Instytut Naukowy - Instytut Śląski w Opolu.

SZÉKELY, Andrea. 2007. "Cross-border Agglomerations.” A Dunaújvárosi Föiskola Közleményei XXIX/3: 239-246.

TEICHERT, Andreas. 2011. "Flucht in den Westen / Ucieczki na Zachód.” Pp. 93-101 in Lebenswege ins Ungewisse / Drogi w nieznane: Görlitz/Zgorzelec 1933-2011, edited by Martina PIETSCH. Görlitz: Schlesisches Museum zu Görlitz.

VOGEL, Michael. 2002. "Anspruch und Realität. Görlitzer Denkmalpflege vor und nach der Wiedervereinigung.” Denkmalpflege in Görlitz 11: 38-42.

WAACK, Christoph. 2000. Stadträume und Staatsgrenzen: Geteilte Städte des mittleren und östlichen Europa im Kontext lokaler Alltagswelten, nationaler Politik und supranationalen Anforderungen. Leipzig: Institut für Länderkunde.

WAACK, Christoph. 2010a. "Bevölkerungsdynamik und Städtebau in Görlitz/Zgorzelec: Die siedlungstopografische Entwicklung der heutigen Europastadt von der Gründerzeit bis 1990." Pp. 18-24 in Heimat und Fremde: Migration und Stadtentwicklung in Görlitz und Zgorzelec seit 1933, edited by Martina PIETSCH. Görlitz: Schlesisches Museum zu Görlitz.

WAACK, Christoph. 2010b. Görlitz/Zgorzelec. Historisch-topografischer Atlas schlesischer Städte / Historyczno-topograficzny atlas miast śląskich. Vol. 1, edited by Peter HASLINGER, Wolfgang KREFT, Grzegorz STRAUCHOLD and Rafał ŻERELIK. Marburg: Herder-Institut.

WEGER, Tobias. 2006. “Görlitz und Zgorzelec nach 1945.” Pp. 34-54 in Görlitz - Zgorzelec. Zwei Seiten einer Stadt / Dwie strony miasta edited by Stella PFEIFFER and Elżbieta OPIŁOWSKA. Dresden: Saxo-Phon.

WENZEL, Peter. 2002. "Kriegsschäden 1945 in Görlitz.” Denkmalpflege in Görlitz 11: 10-40.

WEILER, Michael. 2013. "Görlitz und Zgorzelec. Entwicklungsperspektiven einer binationalen Doppelstadt.” Pp. 217-225 in Colloquium Opole 2012: Miasta w przestrzeni środkowoeuropejskiej: Opole - Görlitz/Zgorzelec - Opawa po roku 1989, edited by Markus BAUER, Monika CHOROŚ, Bernard LINEK and Michał LIS. Opole: Państwowy Instytut Naukowy - Instytut Śląski w Opolu.

WILKOMMENSBÜNDNIS GÖRLITZ. 2017. "Zahlen und Fakten.” Retrieved February 22, 2017 (https://www.willkommensbuendnis-gr.de/zahlen-und-fakten/). 
WÓYCICKI, Kazimierz. 2013. Zuhause an der Neiße. Görlitz und Zgorzelec 1945-1989. Chronik der Ereignisse / Dom nad Nysq: Zgorzelec i Görlitz 1945-1989. Kronika wydarzeń. Görlitz/Zgorzelec: Gajt.

ZIĘBA, Ryszard and Justyna ZAJĄC. 2009. Polska w stosunkach międzynarodowych 1945-1989 [Poland in international relations 1945-1989]. Toruń: Adam Marszałek.

ZUBRZYCKI, Piotr. 2009. Przedmieście Nyskie/Die Neißer Vorstadt. Zgorzelec: Muzeum Łużyckie.

\section{Author}

Dariusz Gierczak received his Master's degree from the Philipps University in Marburg. $\mathrm{He}$ is member of the research team of the Historical-Topographical Atlas of Silesian Towns at the Herder Institute in Marburg. His fields of interest are population geography, demography, migration, urban studies, Eastern European history and cartography.

Contact: dariusz.gierczak@herder-institut.de 